\title{
Climate variability, economic growth, and civil conflict
}

\author{
Vally Koubi \\ Center for Comparative and International Studies (CIS) \& Institute for Environmental Decisions (IED), ETH \\ Zürich, University of Bern \& Oeschger Institute for Climate Change Research
}

Thomas Bernauer

Center for Comparative and International Studies (CIS) \& Institute for Environmental Decisions (IED), ETH Zürich

Anna Kalbhenn

European Central Bank (ECB)

Gabriele Spilker

Center for Comparative and International Studies (CIS) \& Institute for Environmental Decisions (IED), ETH Zürich

\begin{abstract}
Despite many claims by high-ranking policymakers and some scientists that climate change breeds violent conflict, the existing empirical literature has so far not been able to identify a systematic, causal relationship of this kind. This may either reflect de facto absence of such a relationship, or it may be the consequence of theoretical and methodological limitations of existing work. In this article we revisit the climate-conflict hypothesis along two lines. First, we concentrate on indirect effects of climatic conditions on conflict, whereas most of the existing literature focuses on direct effects. Specifically, we examine the causal pathway linking climatic conditions to economic growth and to armed conflict, and argue that the growth-conflict part of this pathway is contingent on the political system. Second, we employ a measure of climatic variability that has advantages over those used in the existing literature because it can presumably take into account the adaptation of production to persistent climatic changes. For the empirical analysis we use a global dataset for 1980-2004 and design the testing strategy tightly in line with our theory. Our empirical analysis does not produce evidence for the claim that climate variability affects economic growth. However, we find some, albeit weak, support for the hypothesis that non-democratic countries are more likely to experience civil conflict when economic conditions deteriorate.
\end{abstract}

\section{Keywords}

civil conflict, climate change, climate variability, democracy, economic growth

\section{Introduction}

The assessment reports of the Intergovernmental Panel on Climate Change (IPCC, 2001, 2007) and the Stern Review (2007) demonstrate that human activity is contributing in important ways to climatic changes, and that those changes have far-reaching effects on plants, animals, ecosystems, and humanity. Among the wide range

Corresponding author:

koubi@vwi.unibe.ch 
of negative effects, climate change tends to exacerbate the scarcity of important natural resources, such as freshwater, and it may trigger mass population dislocations (migration) due to extreme weather events, droughts, floods, desertification, and rising sea-levels. Could these developments increase the risk of violent conflict within and between countries?

The IPCC's Third and Fourth Assessment Reports (IPCC, 2001, 2007) as well as a recent study by the German Advisory Council on Global Change (WBGU, 2008) refer to a possible link between climate change and violent conflict. Furthermore, recent scientific work seems to support such a link (Devitt \& Tol, 2012; Burke et al., 2009; Miguel, Satyanath \& Sergenti, 2004).

High-ranking policymakers have also, on many occasions, warned that climate change may contribute to armed conflict. For instance, UN Secretary-General Ban Ki-moon (2007) has argued that 'The Darfur conflict began as an ecological crisis, arising at least in part from climate change.' President Obama (2009) has stated that 'No nation, however large or small, wealthy or poor, can escape the impact of climate change. More frequent drought and crop failures breed hunger and conflict in places where hunger and conflict already thrive.'

In contrast to such unambiguous statements by some policymakers, even a cursory review of the existing scientific literature reveals that there is rather little consensus on the climate-conflict relationship (for critical reviews, see Buhaug, Gleditsch \& Theisen, 2010; Salehyan, 2008; Nordås \& Gleditsch, 2007; Gleditsch, 1998). A better understanding of whether or not, and if so under what conditions, climatic changes contribute to violent conflict is very important not only for scientific reasons, but also because of its policy implications. If climatic changes do indeed contribute to violent conflict, this could serve as a powerful argument in favor both of drastic cuts of emissions of greenhouse gases and of providing climate adaptation support to vulnerable countries, which are often also the poorest ones. The recent Himalayan glaciers episode of the IPCC (2010) reminds us, however, that we need robust scientific evidence when advocating costly policies. In addition, a better understanding of pathways leading from climate change to conflict (to the extent they exist) can help in avoiding or reducing, through appropriate policies, conflict-promoting effects of climate change.

In this article, we study the climate change-civil conflict nexus by examining the relationship between climate variability and conflict. ${ }^{1}$ We contribute to the existing literature on the climate-conflict relationship (e.g. Buhaug, 2010; Theisen, Holtermann \& Buhaug, 2011-12; Burke et al., 2009; Buhaug, Gleditsch \& Theisen, 2010; Salehyan, 2008; Raleigh \& Urdal, 2007; Hendrix \& Glaser, 2007; Miguel, Satyanath \& Sergenti, 2004) in several ways. First, while most of the existing literature empirically tests the climate-conflict hypothesis in the form of a direct relationship, we submit that climatic changes are likely to affect the potential for violent conflict via negative effects on economic growth - an argument also adopted in the empirical works of Miguel, Satyanath \& Sergenti (2004). Hence our theoretical argument specifies a causal pathway leading from climatic conditions through economic growth to civil conflict, and our empirical analysis is designed to test this two-step causal argument. Second, we argue that political system characteristics, notably democracy, may mediate conflict-promoting effects of sluggish economic growth. By implication, we argue that democratic systems are likely to be better equipped for avoiding violent conflict when climatic changes reduce economic growth. ${ }^{2}$ Third, we employ a measure of climate variability that we think is better suited for identifying the effects of climatic developments on the probability of civil conflict. This measure takes into account that choices regarding production structures (e.g. crop choices, methods of cultivation, choices regarding infrastructures and energy production) tend to be climate-specific and are also adapted to persistent changes in climatic conditions.

The next section reviews the relevant literature. We then develop the theoretical argument. In the fourth section we discuss the empirical approach, and then present the results in the subsequent section. The final

\footnotetext{
${ }^{1}$ Climate change is a phenomenon that unfolds over long periods of time. This poses difficulties for testing directly its relationship with political and economic developments; reliable information on the latter variables (in particular economic performance) is available only for the past few decades, especially for countries that have experienced civil conflict (e.g. sub-Saharan countries). Consequently, we examine the effects of climate variability on conflict onset. While climate change and climate variability are different analytic constructs, they are likely to have common effects on conflict. For instance, studying the effects of a persistent period of high temperatures could yield imperfect yet useful insights into the effects of global warming.

${ }^{2}$ Brückner \& Ciccone (2007) also argue that democratic institutions might mediate civil war onset (if measured using the more than 1,000 battle deaths threshold) better than autocratic ones when economic conditions deteriorate. In their empirical analysis, however, they instrument economic growth with international commodity price growth.
} 
section summarizes the findings and discusses their policy implications.

\section{Literature review}

One major consequence of global warming could be greater scarcity and variability of renewable resources in many parts of the world (IPCC, 2001, 2007). With increasing concerns about such global effects of climate change, a group of scholars, commonly referred to as neo-Malthusians, posits that climate change is a threat to international security because it could increase resource scarcity (WBGU, 2008; Homer-Dixon, 1999; Homer-Dixon \& Blitt, 1998; Bächler et al., 1996). Other scholars, commonly referred to as cornucopians or resource optimists, do not share this pessimistic view. They believe that humanity can adapt to increasing resource scarcity through appropriate market mechanisms (pricing), technological innovation, and other means (Lomborg, 2001; Simon, 1998).

The neo-Malthusian argument has been criticized for being overly complex and deterministic, and for ignoring important economic and sociopolitical factors (e.g. Gleditsch, 1998; Barnett \& Adger, 2007; Salehyan, 2008). Critics have argued that scarcity of renewable resources is only one of the many factors in the overall relationship between climate change and conflict. Buhaug, Gleditsch \& Theisen (2010) reject the idea that climate change has a direct effect on the likelihood of conflict and propose several causal pathways through which economic and political instability, social fragmentation, and migration could increase the probability of climate change leading to armed conflict.

Qualitative case studies provide some, albeit anecdotal evidence that climatic factors can induce environmental degradation (such as increased water scarcity, soil degradation, or deforestation) and contribute to conflict in some parts of the world (e.g. the Sahel region). But it remains unclear to what extent these case-specific findings can be generalized. Large- $\mathrm{N}$ studies have, so far, not been able to provide conclusive evidence in support of one or the other side in the debate. As the brief literature review below shows, persisting disagreement is at least in part due to the use of different measures of climatic change, and different sample sizes and time periods.

Hendrix \& Glaser (2007) examine the impact of short-term climatic changes (interannual variability in rainfall) on civil conflict onset in sub-Saharan Africa. They report that positive changes in rainfall significantly decrease the conflict risk in the following year. Similarly Miguel, Satyanath \& Sergenti (2004) - henceforth referred to as MSS - study 41 African countries in 1981-99 and find that lower rainfall growth reduces economic growth and, indirectly, increases the probability of intrastate conflict. Brückner \& Ciccone (2007, 2010), on the other hand, do not find any significant effects of rainfall growth on civil war onset. Jensen \& Gleditsch (2009) point out that MSS's finding is due to the inclusion of cases where countries participate in civil wars in other states. They show that exclusion of these cases reduces the estimated effects of rainfall growth on civil conflict. Ciccone (2011) also reevaluates the MSS findings using rainfall levels instead of rainfall growth rates. He reports that lower rainfall levels are associated with a lower probability of civil conflict. Ciccone's criticism of MSS has two components. First, he claims that the use of rainfall growth rates is not an appropriate measure of a rainfall shock because of mean reversion in rainfall levels. This means that the growth rate of rainfall may take a negative value and indicate an adverse effect of climate variability on economic conditions even when the level of rainfall is above its normal level. Second, if the growth rate of rainfall is indeed the relevant climatic variable, then the estimation can still be done using rainfall levels, but it imposes testable sign restrictions on the various lagged levels. According to Ciccone, these sign restrictions are not satisfied by the coefficients estimated by MSS. Ciccone's first - and most important - criticism seems compelling. The second one, however, is more difficult to implement without strong exclusion restrictions (see Miguel \& Satyanath, 2010).

Hendrix \& Salehyan (2012) also focus on Africa. They investigate the effect of deviations from normal rainfall patterns on civil conflict as well as civil unrest (e.g. riots, strikes) during the last 20 years. They find that wetter and drier than normal conditions are associated with both civil conflict and civil unrest. Zhang et al. (2007) hypothesize that climate change affects conflict through its effects on agricultural productivity. Bivariate correlations over the period 1400-1900 indicate that changes in average temperature are related to changes in agricultural production and the frequency of wars. Devitt \& Tol (2012) rely on a simulation model to examine the interaction between climate change, economic growth, and civil war. They report that climate change (higher temperature) through its negative impact on economic growth will increase the probability of civil war by $1 \%$ in Lesotho in 2100 . Theisen, Holtermann \& Buhaug (2011-12), using various drought measures, do not find any effect of drought on civil conflict in Africa during the 1960-2004 period. Burke et al. (2009), on 
the other hand, find that temperature increases in Africa between 1981 and 2002 have a significant, positive effect on the occurrence of civil war. Buhaug (2010) shows, however, that this result is not robust to alternative model specifications. He also finds that climate variability, measured as interannual growth and deviation from annual mean precipitation and temperature, is a poor predictor of civil conflict. Bergholt \& Lujala (2012) also do not find significant effects of hydro-meteorological disasters (an instrument for economic growth) on the likelihood of civil conflict.

Most research in this area has focused on identifying a direct link between climatic conditions and conflict. ${ }^{3}$ The absence of a direct effect, however, does not necessarily imply the absence of any effect. An alternative, useful research strategy is to look for conditional effects that vary with the level of economic performance and the political system in place. Furthermore, the use of growth rates in rainfall might not be a suitable measure because rainfall growth is mean reverting (see Ciccone, 2011; Buhaug, 2010). It may thus fail to capture the true economic impact of rainfall because it is not conditioned on its 'normal' level. In this article we propose a politically moderated relationship between climate change and conflict that involves conditional effects (through economic performance and political institutions). Moreover, we evaluate this relationship using a measure of climatic conditions that is both more compelling theoretically and more immune to problems of endogeneity.

\section{A politically moderated relationship}

Our argument starts with the assumption that climate change per se is unlikely to trigger civil conflict. However, it is possible that certain changes in rainfall and temperature, coupled with volatile weather patterns swinging between extremes, could reshape the productive landscape of entire regions and exacerbate food, water, and energy scarcities, as envisaged in the traditional resource scarcity (neo-Malthusian) model. Consequently, we argue that climatic changes, through their effects on economic growth, might induce competition among groups inside a state and thus increase the likelihood of conflict. However, violence is likely to occur only in states where the capacity for dealing with climate-induced economic deterioration and associated conflict potential is low. We argue that democratic institutions, such as those imposing constraints on the

\footnotetext{
${ }^{3}$ Bergholt \& Lujala (2012), Zhang et al. (2007), Miguel, Satyanath $\&$ Sergenti (2004) are notable exceptions.
}

executive, separating power, creating a large number of veto players in public policymaking, and safeguarding property rights, collectively serve to strengthen the rule of law and thus mitigate conflict. The remainder of this section elaborates on the pathway through which climate variability could, via its effects on economic conditions, lead to civil conflict.

\section{Climate change and economic growth}

Climate and weather can impact on many human activities, from leisure to agriculture to industrial production. However, estimating the consequences of climate change for economic growth is difficult. The main reason is that the impact of climate change will vary with levels of economic development and the political capacity of a country, with levels and types of climatic conditions (more/ less rain, higher/lower temperature, more/less frequent and/or intense storms, etc.). In other words, although economic and political actors respond to climatic conditions by developing and implementing adaptation strategies, their ability to do so depends critically on institutional, economic, and technological capabilities.

The existing literature provides some evidence that climatic changes affect economic output (GDP), for example by reducing agricultural yields when temperature rises (precipitation falls) (e.g. Mendelsohn et al., 1998; Mendelsohn, Dinar \& Williams, 2006; Nordhaus \& Boyer, 2000; Tol, 2002; Deschenes \& Greenstone, 2007; Barrios, Bertinelli \& Strobl, 2010). Such evidence also suggests that climatic changes should affect economic growth. One can even suspect that the effect on economic growth is more distinct: if climatic changes affected only the level of economic output, we would observe mostly a short-term effect. This should be the case as for example a rise in temperature (decrease in precipitation) would be compensated by subsequent temperature decreases (precipitation increases) - due, for example, to stringent abatement of emissions - which should then return the GDP to its previous level. But this is not the case if climatic changes affect economic growth. The reasons are the following. First, economic growth will be lower even if GDP returns to its previous level because of forgone consumption and investment due to lower income during the period of higher temperature (lower precipitation). In addition, as long as countries spend some resources adapting to climatic changes, they incur opportunity costs in terms of not spending these resources on R\&D and capital investment. This has negative effects on economic growth. Moreover, given the short time series used in existing research on the effects of climate on economic 
conditions, even slightly persistent effects on the level of output will impact on the sample mean of growth. That is, using economic growth rates will also capture the effects on GDP levels. But using the level of GDP instead of its growth rate may miss the effects on the growth rate. For these reasons we concentrate on the effects of climate variability on economic growth.

The empirical literature offers some evidence that climatic conditions affect economic growth. For instance, Miguel, Satyanath \& Sergenti (2004) find that rainfall growth increases economic growth in Africa. Dell, Jones \& Olken (2008) show that higher temperatures have negative effects on economic growth, but only in poor countries, whereas precipitation has no effect. Hence we expect that climate variability should affect economic growth.

\section{Economic growth and conflict}

Previous research has shown that reduced levels of domestic economic activity tend to create incentives for conflict. ${ }^{4}$ Building on this research, we posit that climate change, by reducing economic growth, affects the utility of individuals and groups to engage in civil conflict. It does so in two ways: first, negative climatic conditions, via their negative effect on economic growth, can reduce resources available to the government (e.g. by reducing tax revenue). The government thus has fewer resources to invest in people, for instance to provide better nutrition, schooling, and on-the-job training that would lead to improved living conditions. It also has fewer resources to provide for the people, for example in terms of sustaining peace through the maintenance of law and order - the latter, for instance, lowers the probability of rebel victory by increasing the cost of rebellion.

Second, climate-related phenomena, such as lower precipitation, higher temperature, and extreme weather events lead to lower personal income from production and also decrease the opportunity for future employment. Consequently, the opportunity cost of rebellion decreases because the expected returns from peaceful employment, say farming, compared to joining criminal or insurgent groups are lower. In situations like these, when individuals expect to earn more from criminal or insurgent activity than from lawful and peaceful activity, predatory behavior becomes more likely. The latter implicates conditions in which each individual or group effort to increase its own welfare reduces the welfare of

\footnotetext{
${ }^{4}$ See Chassang \& Padro-i-Miquel (2010), Garfinkel \& Skaperdas (2007), Collier \& Hoeffler (2004), Fearon \& Laitin (2003). See also Blattman \& Miguel (2010) for a critical review of the literature.
}

others and also increases the probability of mutual attacks (Jervis \& Snyder, 1999).

The argument that poverty breeds conflict and war is supported by several empirical studies (e.g. Hidalgo et al., 2010; Dube \& Vargas, 2008; Hegre \& Sambanis, 2006; Collier \& Hoeffler, 2004; Miguel et al., 2004; Fearon \& Laitin, 2003). For example, Collier \& Hoeffler (2004) find that low economic growth, which is a proxy for foregone earnings, increases the risk of conflict. Dube \& Vargas (2008) show that a drop in the price of coffee substantially increased the incidence and intensity of intrastate conflict in coffee-intensive areas in Colombia in 1994-2005. They attribute this result to the lowering of opportunity costs of joining a rebel movement (via depressed wages) in these areas. Hidalgo et al. (2010) also show that land invasions by the rural poor in Brazil occur immediately after adverse economic shocks, which in the statistical analysis are instrumented by rainfall.

\section{Political regimes/institutions and conflict}

As discussed above, we expect the probability of violent conflict to increase when economic conditions deteriorate due to climatic changes: individuals anticipate that their returns from labor diminish, and the ability of the government to provide goods and services for the people and to maintain order decays. This decreases the opportunity costs of engaging in political violence. We submit, however, that armed conflict is more likely to occur in states where existing institutions and mechanisms for conflict resolution cannot provide people with the assurance that climate-induced economic problems will be resolved without recourse to violence. Formal institutions that help enforce commitments intertemporally can mitigate commitment problems in situations in which each individual or group's effort to increase its own well-being reduces the well-being of others. ${ }^{5}$ Consequently we posit that democratic institutions that 'restrain the dark side of self-interest', 6 such as a constrained executive and separation of powers, a civil society, elections, an independent judiciary, as well as the rule of law, collectively work to reduce the risk of conflict. Conversely, societies with weak government institutions and few checks and balances are likely to be more prone to armed conflict. This implies that autocratic countries are more likely to experience intrastate

\footnotetext{
5 See Powell (2006) on the commitment problem and Snyder \& Jervis (1999) on mutual fears and security.

${ }^{6}$ Skaperdas (2003: 135).
} 
conflict than democratic countries when economic conditions deteriorate due to climatic changes.

The main reasons why democracies are expected to mitigate conflict are the following: in democratic political systems citizens are informed by independent mass media about the state of their environment and economy as well as government policies and they can thus subject their government's actions to close scrutiny. They also have the opportunity to express freely their opinions and organize around alternative political views (Payne, 1995). Political parties are not only instrumental in aggregating preferences and representing interests, thus solving the collective action problem, but also in managing conflict since they help decrease uncertainty about the intentions and actions of important political actors (Aldrich, 1994). Moreover, through electoral mechanisms opposition parties are free to redress their grievances $^{7}$ and express their preferences without state repression. Elections also provide political leaders with incentives to satisfy their citizens' demands if they wish to retain power. In addition, since democratic political leaders are responsive to a larger winning coalition and lack sufficient resources to reward their comparatively large group of supporters with private goods, they have to resort to the provision of public goods - including economic prosperity - to ensure political support and, thus, their survival in office (Bueno de Mesquita et al., 2003). Furthermore, an independent legislature ensures the representation of a broad range of interests and also guarantees that no group will have to suffer from (governmental) policies and actions that are considered to be detrimental to its own interests. Finally, an independent judiciary, by ensuring that the rule of law is observed and maintained, preserves political stability and increases the legitimacy of the state.

Studies on the relationship between political institutions and intrastate conflict have mostly focused on the effects of democracy and have thus far produced mixed results. While several studies (e.g. Collier \& Hoeffler, 2004; Fearon \& Laitin, 2003) find that democracy is not a good predictor of the probability of intrastate conflict, others (e.g. Gleditsch \& Ruggeri, 2010; Elbadawi \& Sambanis, 2002) show that democracy has a negative effect on civil conflict onset. Furthermore, Gleditsch,

\footnotetext{
${ }^{7}$ Reynal-Querol (2002) argues that what matters for conflict is not necessarily the degree of democracy but rather the type of democracy. She shows that proportional representation systems have a lower probability of experiencing a civil war than majoritarian ones because such systems are likely to be more inclusive and hence curb grievances.
}

Hegre \& Strand (2009), Reynal-Querol (2002), Sambanis (2001), and Hegre et al. (2001) find that partly democratic countries (that is, semi-democracies, meaning regimes in the middle range of the democracy-autocracy Polity index) are more prone to intrastate conflict than full democracies and full autocracies. All these studies, however, examine the direct effect of democracy on intrastate conflict, whereas we are interested in the interaction effect of democracy and climate-impacted economic growth on intrastate conflict. ${ }^{8}$

\section{Methods and data}

We test our argument on the climate variability-economic growth-conflict relationship using panel data from all countries of the world in the period 1980-2004.

Rather than using an instrumental variable approach merely as a technical solution, as previous studies have done (e.g. Miguel et al., 2004), our theoretical considerations suggest that climate variability may indirectly affect the probability of intrastate conflict via its effect on economic growth. For this reason we employ a two-stage procedure, ${ }^{9}$ taking into account that conflict and the state of the economy are not independent of each other (see Blomberg, Hess \& Thacker, 2006; Blomberg \& Hess, 2002). We use measures of precipitation and temperature to estimate per capita economic growth in the first stage of the model (subscript 1):

$$
\begin{aligned}
\text { growth }_{i t}=\alpha_{1 i} & +\beta_{1,0} \operatorname{Pre}_{i t}+\beta_{1,1} \text { Temp }_{i t} \\
& +\mathrm{c}_{1} \mathrm{X}_{i t}+\mathrm{d}_{1} \text { year }+\mathrm{e}_{1 i t}
\end{aligned}
$$

where Pre and Temp are measures of climate variability, $X$ are other exogenous variables, year denotes a linear time trend, $\beta, c$ and $d$ are coefficients to be estimated, $\alpha$ is a country fixed effect (see below) and $e$ is an iid error term.

In order to be able to introduce an interaction term between economic growth and a country's political system in the second stage, we estimate

$$
\begin{array}{rl}
\text { growth }_{i t} & * \text { democracy }_{i, t-1}=\alpha_{1 i}+\beta_{1,0} \operatorname{Pre}_{i t} \\
& +\beta_{1,1} \text { Temp }_{i t}+\mathrm{c}_{1} \mathrm{X}_{i t}+\mathrm{d}_{1} \text { year }+\mathrm{e}_{1 i t}
\end{array}
$$

We then estimate the effect of predicted income growth and the predicted interaction term on intrastate conflict in the second-stage equation (subscript 2):

\footnotetext{
${ }^{8}$ Gizelis \& Wooden (2010) make a similar argument pertaining to the impact of water scarcity on conflict and find evidence that democracy mediates water scarcity on civil conflict onset.

${ }^{9}$ A similar procedure is employed by Bergholt \& Lujala (2012).
} 


$$
\begin{aligned}
& \text { conflict }_{i t}=\alpha_{2 i}+\gamma_{2,0} \text { growth }_{i, t-1}(\text { predict }) \\
&+\gamma_{2,1} \text { democracy }_{i, t-1}+\gamma_{2,2} \text { growth }_{i, t-1} \\
&\left.* \text { democracy }_{i, t-1}\right)(\text { predict })+\mathrm{c}_{2} Z_{i t}+\mathrm{d}_{2,1} \text { peaceyears } \\
&+\mathrm{d}_{2,2} \text { peaceyears } \\
& 2
\end{aligned}
$$

Equation (1) is estimated using the fixed effects vector decomposition (fevd) estimator by Plümper \& Tröger (2007). This estimator allows us to include time invariant variables alongside country fixed effects. We also correct for autocorrelation.

Equation (2) is estimated using logit regression with bootstrapped standard errors. ${ }^{10}$ To model temporal dependence, time since the last conflict as well as the squared and cubic terms (peaceyears) are included in the model (Carter \& Signorino, 2010). This approach acknowledges that the likelihood of intrastate conflict onset at present depends strongly on conflict that occurred in the years before and thus controls for time effects.

\section{Variables and data sources}

Economic growth. The dependent variable in the first equation is economic growth. We use the data on economic growth from the Penn World Tables Version 6.2 (Heston, Summers \& Aten, 2006).

Onset of civil conflict. We use data on civil conflict onset from the Onset of Armed Conflict Dataset, a joint project of the Uppsala Conflict Data Program and the Centre for the Study of Civil War at the Peace Research Institute Oslo (see Gleditsch et al., 2002). An armed civil conflict is defined in the UCDP/PRIO database (Strand, 2006) as a contested incompatibility that concerns government and/or territory where the use of armed force between two parties, of which one is the government of the state, results in at least 25 battle-related deaths. We use the onset variable that specifies a nine-year intermittency threshold. This means that for a new conflict onset to occur, the country must not have had any civil conflict within the past nine years.

\footnotetext{
${ }^{10}$ Another possibility would be to use the estimator proposed by Maddala (1983), which is designed to test a two-equation system with a dichotomous endogenous variable (see also Keshk, 2003). In contrast to the approach described by Maddala (1983), we need to incorporate in the second equation the interaction effect between democracy and the predicted values for economic growth from the first equation. Doing so in the context of Maddala's approach is, however, not straightforward. This is why we opted for the procedure described above.
}

Climate variables. We use measures of precipitation and temperature to estimate the impact of climate on economic growth and subsequently on the probability of conflict onset. While many environmental variables such as water scarcity and soil erosion are directly affected by human behavior, climate variability is a large-scale phenomenon that is beyond human control at the local level and within the short to medium term. Thus, using precipitation and temperature avoids the endogeneity problem that plagues much of the literature on the neo-Malthusian hypothesis.

Our climate variables are defined in terms of the deviation of the current level of precipitation and temperature from their past, long-run level (defined as a 30 -year moving average of past values). In the existing literature, most studies use levels of rainfall and/or growth in rainfall (e.g. Miguel et al., 2004; Hendrix \& Glaser, 2007; Brückner \& Ciccone, 2007, 2010) and precipitation/temperature deviation from the sample mean (i.e. Buhaug, 2010; Hendrix \& Salehyan, 2012). We believe that Ciccone's (2011) criticism of studies that use the growth rate of rainfall is appropriate. Nonetheless, his proposed measure of rainfall levels is problematic because of the possibility that the choice of production structure (e.g. crop choices, choices regarding infrastructure and energy production) may be climatespecific. If so, then the level of rainfall does not accurately capture the economic consequences of climatic variability. For example, high rainfall levels in a region that is adapted to dry weather conditions could be as detrimental as low rainfall in a region that is adapted to wet conditions. Country fixed effects cannot deal with this problem to the extent there is adaptation to changing climatic conditions. ${ }^{11}$ Hence our climate measure has an advantage over those that simply rely on levels.

Our data sources are the Global Precipitation Climatology Centre (GPCC) (Beck, Grieser \& Rudolf, 2004), the Climatic Research Unit (Mitchell \& Jones, 2005) for precipitation, and CRUTEM3 (Brohan et al., 2006) and the Climatic Research Unit (CRU) (Mitchell \& Jones, 2005) for temperature. As a robustness check we use the Standardized Precipitation Index (SPI6) (McKee, Doesken \& Kleist, 1993).

\footnotetext{
${ }^{11}$ While the commodities price index used by Brückner \& Ciccone $(2007,2010)$ seems more informative than current growth in rainfall, it is still not as appropriate as our measure because it may suffer from endogeneity problems, and it is not as country-specific as the climate variable.
} 
Political institutions (xpolity). Our indicator for democracy is based on the combined Polity score from the Polity IV dataset. Polity assigns scores to democracy according to three components: competitiveness of executive recruitment (XRCOMP), openness of executive recruitment (XROPEN), and competitiveness of participation (PARCOMP). Since the competitiveness of participation component makes explicit reference to civil conflict (Vreeland, 2008), we use the xpolity data by Vreeland (2008), which excludes the participation dimension of the original Polity IV data. We also check the robustness of our results using the original Polity IV index (Marshall \& Jaggers, 2004). To capture the interaction effect between a country's political institutions and growth in the second equation, we introduce an interaction term between the two variables. ${ }^{12}$

\section{Control variables}

GDP per capita and initial per capita income. Since income convergence plays a key role in all economic growth theories and is always included in empirical studies of economic growth, we use the initial real income to capture convergence factors. In addition, we include the lagged value of the log of GDP per capita to control for the stylized fact that poverty breeds conflict, that is, the hypothesis that civil conflict is observed mostly in poor countries. We use data from Gleditsch (2002), which is an enhanced version of the Penn World Tables Version 6.2 (2006).

Population. We include population size and population growth because population is considered to be an important determinant of civil conflict (North, 1984; Homer-Dixon, 1999; Hegre \& Sambanis, 2006). For example, North (1984) claims that a growing population creates an increasing demand for resources and concludes that states with high population growth and inadequate resources are more conflict prone. Fearon \& Laitin (2003) also argue that a large population implies difficulties in controlling local level activity and increases the number of potential rebels that can be recruited by the insurgents. Simon (1998), however, posits that as long as population growth stimulates advances in technology, the

\footnotetext{
${ }^{12}$ Democracy could be endogeneous to conflict, in which case we should have an instrument for democracy (Elbadawi \& Sambanis, 2002). However, given our interest in the mediating effect of democracy on conflict, we believe that the lag value of the xpolity is sufficient to alleviate endogeneity concerns.
}

economic motivation for territorial expansion will diminish and wars driven by population growth may be less common in the future. We use data from Gleditsch (2002).

Ethnolinguistic fractionalization. Although there is disagreement in the literature on the relationship between the heterogeneity of a country's population and its propensity for intrastate conflict (e.g. Fearon \& Laitin, 2003; Cederman \& Girardin, 2007), we account for the possibility that ethnolinguistic fractionalization affects the potential for civil conflict. We use data from Fearon \& Laitin (2003).

Rough terrain. Fearon \& Laitin (2003) argue that mountainous countries are likely to experience a higher risk of civil conflict because rebels find it easier to hide in mountains and forests. We control for this potential effect, measuring rough terrain by the estimated percentage of mountainous terrain and using data from Fearon \& Laitin (2003).

Oil-exporting countries. Proponents of the 'resource curse' argument claim that civil conflict is more likely in oil-producing countries. The reason is that 'oil revenues raise the value of the "prize" of controlling state power' and oil-exporting countries tend to have weaker state apparatuses (Fearon \& Laitin, 2003: 81). To control for this possibility we include an indicator for countries in which oil constitutes more than one-third of export revenues. We use data from Fearon \& Laitin (2003).

Regional dummy variables and time trend. We include regional dummy variables, with Europe serving as the baseline category, to control for any regional variation in both economic growth and conflict. We also introduce a linear time trend in the model to explain economic growth.

Descriptive statistics are shown in the Appendix.

\section{Results}

Table I reports the results from the regression of income growth on climate variability and the control variables described above. It does so for two samples: all countries and African countries only.

We conduct a separate analysis for Africa because much of the existing literature focuses on Africa (and often on sub-Saharan Africa only). The reason for focusing on Africa is that agriculture is the most important sector in these economies and a high percentage of the 
population lives in rural areas. At the same time, water storage capacity (dams, reservoirs) and the percentage of irrigated land in Africa are the lowest in the world. In combination with low economic and state capacity, this is likely to make these countries more vulnerable to climatic changes. African countries also experience more frequent civil conflict than other parts of the world. Hence they constitute critical cases. That is, if we cannot detect a climate variability effect on civil conflict in Africa, such an effect is, presumably, unlikely to exist in other parts of the world. We think that this justification sounds plausible, but also think that an explicit empirical test is better, notably because agriculture is also important in other regions of the world, for example in Asia and Latin America, and because climate variability is occurring in other regions as well.

The results show that there is no statistically significant impact of climate variability on economic growth. This finding is independent of the sample used. Hence our analysis does not support the argument that economic growth is affected by climate variability. Table II reports the results from the regression of civil conflict onset on predicted economic growth. ${ }^{13}$

Because we use a multiplicative term of lagged predicted growth and lagged democracy, the main effect of interest in this regression is best understood when presented in graph form. Figure 1 shows the coefficients of predicted economic growth on the likelihood of civil conflict onset at different values of the democracy variable for the sample including all countries. If the vertical lines, which show the confidence intervals of the respective point estimate, do not cross the zero line, the coefficient on predicted economic growth is significant for the respective value of the democracy variable. Figure 1 shows that predicted economic growth has a statistically significant effect on civil conflict onset for certain xpolity scores that indicate autocracies, but not in democracies. However, Figure 2 does not confirm this result for the African subsample. Here the coefficients of predicted economic growth never reach standard significance levels for any xpolity score. ${ }^{14}$ Overall, the results from the second stage estimation offer some,

\footnotetext{
${ }^{13}$ Although we use the two-stage procedure for theoretical reasons, the second-stage results should be interpreted with caution since we do not find a significant impact of climate variability on economic growth in the first stage.

${ }^{14}$ Miguel, Satyanath \& Sergenti (2004) did not find any significant interaction effects between economic growth and democracy in their study of African countries.
}

Table I. Climate variability and economic growth

\begin{tabular}{|c|c|c|}
\hline & $\begin{array}{c}\text { (1) } \\
\text { World, } \\
\text { MA } 30\end{array}$ & $\begin{array}{c}\text { (2) } \\
\text { Africa, } \\
M A 30\end{array}$ \\
\hline Temperature MA 30 & $\begin{array}{c}-0.22 \\
(0.53)\end{array}$ & $\begin{array}{c}-1.13 \\
(3.83)\end{array}$ \\
\hline Precipitation MA 30 & $\begin{array}{c}0.00 \\
(0.00)\end{array}$ & $\begin{array}{c}0.00 \\
(0.00)\end{array}$ \\
\hline Xpolity, lagged & $\begin{array}{c}-0.05 \\
(0.35)\end{array}$ & $\begin{array}{c}0.02 \\
(0.50)\end{array}$ \\
\hline Population growth & $\begin{array}{c}11.98 \\
(11.49)\end{array}$ & $\begin{array}{l}47.13^{* *} \\
(20.22)\end{array}$ \\
\hline Log population, lagged & $\begin{array}{c}3.65 \\
(6.35)\end{array}$ & $\begin{array}{c}-3.69 \\
(34.17)\end{array}$ \\
\hline Log GDP/capita, lagged & $\begin{array}{c}-9.43^{* * *} \\
(2.18)\end{array}$ & $\begin{array}{c}-6.27 \\
(6.97)\end{array}$ \\
\hline Trend & $\begin{array}{c}0.15 \\
(0.25)\end{array}$ & $\begin{array}{c}0.10 \\
(0.98)\end{array}$ \\
\hline Oil & $\begin{array}{c}0.52 \\
(2.86)\end{array}$ & $\begin{array}{c}3.62 \\
(29.29)\end{array}$ \\
\hline Ethnic fractionalization & $\begin{array}{c}-6.33 \\
(4.85)\end{array}$ & $\begin{array}{c}-1.77 \\
(66.55)\end{array}$ \\
\hline Rough terrain & $\begin{array}{c}-2.07 \\
(1.35)\end{array}$ & $\begin{array}{c}0.91 \\
(14.24)\end{array}$ \\
\hline GDP initial & $\begin{array}{c}0.00^{* *} \\
(0.00)\end{array}$ & $\begin{array}{c}0.00 \\
(0.01)\end{array}$ \\
\hline North Africa & $\begin{array}{r}-12.15^{*} \\
(7.38)\end{array}$ & \\
\hline Sub-Saharan Africa & $\begin{array}{c}-15.08^{* * *} \\
(4.81)\end{array}$ & \\
\hline East Asia & $\begin{array}{c}-7.24 \\
(4.77)\end{array}$ & \\
\hline West Asia & $\begin{array}{r}-13.79 \\
(8.60)\end{array}$ & \\
\hline Middle East & $\begin{array}{c}-8.07 \\
(6.85)\end{array}$ & \\
\hline Latin America & $\begin{array}{c}-6.88 \\
(4.53)\end{array}$ & \\
\hline North America & $\begin{array}{c}-0.78 \\
(12.75)\end{array}$ & \\
\hline$\eta$ & $\begin{array}{c}0.87 \\
(0.00)\end{array}$ & $\begin{array}{c}0.96 \\
(0.00)\end{array}$ \\
\hline Constant & $\begin{array}{c}52.91 \\
(34.63)\end{array}$ & $\begin{array}{c}71.11 \\
(184.98)\end{array}$ \\
\hline Observations & 2818 & 1321 \\
\hline
\end{tabular}

Standard errors in parentheses; * significant at $10 \%$; ${ }^{* *}$ significant at $5 \%$; ${ }^{* * *}$ significant at $1 \%$.

Both models are estimated using the fixed effects vector decomposition (fevd) estimator by Plümper \& Tröger (2007).

albeit weak, support for the theoretical argument that economic growth can have an effect on civil conflict primarily in non-democratic countries. 
Table II. Predicted economic growth and civil conflict

\begin{tabular}{|c|c|c|}
\hline & $\begin{array}{l}\text { (1) } \\
\text { World conflict, } \\
\text { MA } 30\end{array}$ & $\begin{array}{c}\text { (2) } \\
\text { Africa Conflict, } \\
\text { MA } 30\end{array}$ \\
\hline Predicted growth, lagged & $\begin{array}{c}-0.04 \\
(0.07)\end{array}$ & $\begin{array}{c}-0.16^{*} \\
(0.09)\end{array}$ \\
\hline Xpolity, lagged & $\begin{array}{c}0.03 \\
(0.05)\end{array}$ & $\begin{array}{c}0.08 \\
(0.06)\end{array}$ \\
\hline $\begin{array}{l}\text { Predicted } \\
\text { (Polity*growth), } \\
\text { lagged }\end{array}$ & $\begin{array}{c}0.02 \\
(0.02)\end{array}$ & $\begin{array}{c}-0.01 \\
(0.03)\end{array}$ \\
\hline Population growth & $\begin{array}{c}7.28 \\
(6.77)\end{array}$ & $\begin{array}{c}15.94 \\
(10.36)\end{array}$ \\
\hline Log population, lagged & $\begin{array}{c}0.21 \\
(0.13)\end{array}$ & $\begin{array}{c}0.10 \\
(0.17)\end{array}$ \\
\hline Log GDP/capita, lagged & $\begin{array}{l}-0.78^{* * *} \\
(0.26)\end{array}$ & $\begin{array}{c}-0.92^{* *} \\
(0.38)\end{array}$ \\
\hline Oil & $\begin{array}{c}1.23^{* *} \\
(0.50)\end{array}$ & $\begin{array}{c}0.42 \\
(0.66)\end{array}$ \\
\hline Ethnic fractionalization & $\begin{array}{l}1.15 \\
(0.77)\end{array}$ & $\begin{array}{c}0.04 \\
(0.98)\end{array}$ \\
\hline Rough terrain & $\begin{array}{c}-0.07 \\
(0.18)\end{array}$ & $\begin{array}{c}0.13 \\
(0.20)\end{array}$ \\
\hline GDP initial & $\begin{array}{c}-0.00 \\
(0.00)\end{array}$ & $\begin{array}{c}0.00 \\
(0.00)\end{array}$ \\
\hline North Africa & $\begin{array}{c}-1.02 \\
(1.20)\end{array}$ & \\
\hline Sub-Saharan Africa & $\begin{array}{c}-2.34^{*} \\
(1.25)\end{array}$ & \\
\hline East Asia & $\begin{array}{c}-2.38^{* * *} \\
(0.86)\end{array}$ & \\
\hline West Asia & $\begin{array}{c}-1.19 \\
(0.97)\end{array}$ & \\
\hline Middle East & $\begin{array}{c}-2.08^{*} \\
(1.08)\end{array}$ & \\
\hline Latin America & $\begin{array}{c}-1.10 \\
(0.99)\end{array}$ & \\
\hline Peace years & $\begin{array}{c}-0.09 \\
(0.09)\end{array}$ & $\begin{array}{c}0.08 \\
(0.15)\end{array}$ \\
\hline Peace years^${ }^{\wedge}$ & $\begin{array}{c}0.01 \\
(0.01)\end{array}$ & $\begin{array}{c}-0.00 \\
(0.01)\end{array}$ \\
\hline Peace years^3 & $\begin{array}{c}-0.00 \\
(0.00)\end{array}$ & $\begin{array}{c}0.00 \\
(0.00)\end{array}$ \\
\hline Constant & $\begin{array}{c}1.45 \\
(2.39)\end{array}$ & $\begin{array}{c}0.70 \\
(2.64)\end{array}$ \\
\hline Observations & 2,746 & 1,356 \\
\hline Log likelihood & -227.1 & -177.1 \\
\hline Pseudo R2 & 0.132 & 0.0541 \\
\hline
\end{tabular}

Bootstrapped standard errors in parentheses.

${ }^{*}$ significant at $10 \%$; ${ }^{* *}$ significant at $5 \%$; ${ }^{* * *}$ significant at $1 \%$.

As to the control variables, only oil production has a positive and statistically significant effect on conflict in the global sample, whereas the log of GDP per capita has

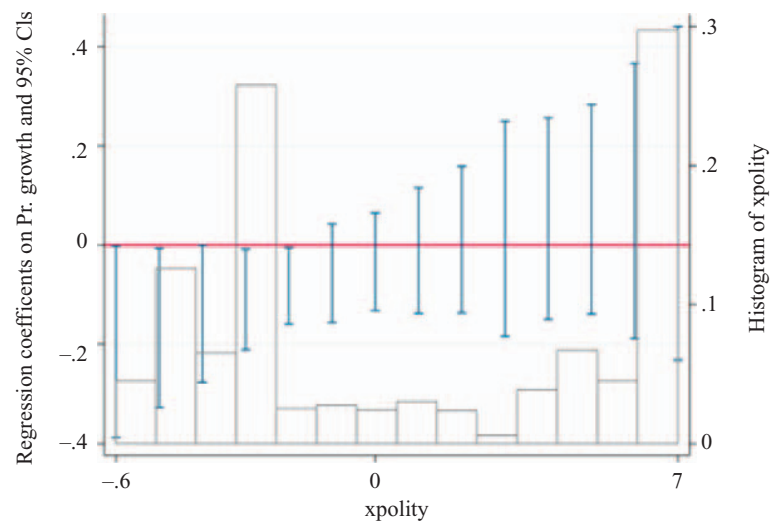

Figure 1. Coefficients of predicted economic growth on civil conflict at different levels of democracy

MA 30 in first stage of the model; fixed effects vector decomposition estimator; sample: world.

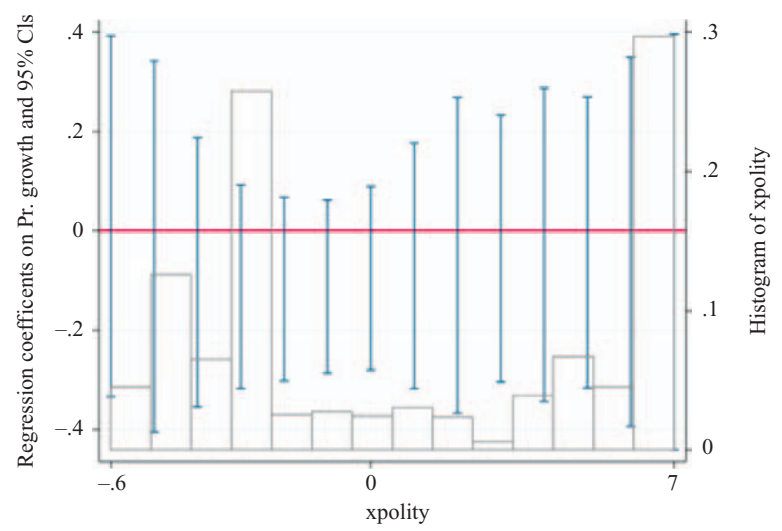

Figure 2. Coefficients of predicted economic growth on civil conflict at different levels of democracy

MA 30 in first stage of the model; fixed effects vector decomposition estimator; sample: Africa.

a negative effect. Presumably due to the lower number of observations, only the log of GDP per capita has a significant and negative effect in the African sample.

\section{Robustness checks}

We have evaluated the robustness of our results to the estimation procedure and to the specification of the variables. Using a fixed effects procedure instead of the fixed effects vector decomposition (fevd) estimator does not change the main results (Tables III and IV). However, in contrast to Figure 1, we do not see a significant effect of predicted growth on the likelihood of conflict onset in Figures 3 and 4. Hence the conclusion that the effect of economic growth on civil 
Table III. Climate variability and economic growth

(1)

(2)

World, MA $30 \quad$ Africa, $M A 30$

\begin{tabular}{lcc}
\hline Temperature ma30 & 0.01 & -0.56 \\
& $(0.25)$ & $(0.55)$ \\
Precipitation ma30 & 0.00 & 0.00 \\
& $(0.00)$ & $(0.00)$ \\
Xpolity, lagged & -0.06 & -0.01 \\
& $(0.06)$ & $(0.10)$ \\
Population growth & $12.10^{*}$ & -5.38 \\
& $(6.22)$ & $(15.99)$ \\
Log population, lagged & $-8.68^{* * *}$ & -4.64 \\
& $(1.63)$ & $(3.34)$ \\
Log GDP/capita, lagged & $-10.13^{* * *}$ & $-6.17^{* * *}$ \\
& $(0.74)$ & $(0.91)$ \\
Trend & $0.39^{* * *}$ & 0.13 \\
& $(0.04)$ & $(0.09)$ \\
Constant & $151.49^{* * *}$ & $83.59^{* * *}$ \\
& $(16.58)$ & $(26.92)$ \\
Observations & 3087 & 1471 \\
R-squared & 0.07 & 0.04 \\
\hline
\end{tabular}

Standard errors in parentheses; ${ }^{*}$ significant at $10 \%$; ${ }^{* *}$ significant at $5 \%$; *** significant at $1 \%$

Both models are estimated using the fixed effects estimator.

conflict is mediated by a country's political system seems fragile.

Using SPI6, instead of our climate variability indicator, does not make any difference either (Tables A.I and A.II in the Web Appendix). Similarly, the figure presenting the interaction effect between predicted growth and xpolity (Figure A.1) resembles Figure 1: if we include all countries of the world we see that economic growth has a negative effect on civil conflict in autocratic countries only. In the same vein, the results are immune to replacing the xpolity indicator of Vreeland (2008) by the standard Polity IV index (see Tables A.III and A.IV in the Web Appendix). Using a threshold of 1,000 rather than 25 battle-related deaths to measure conflict onset does not change the results either (Tables A.V and A.VI in the Web Appendix).

Finally, we ran our regression models on a sample including particularly poor countries, namely those defined as 'the bottom billion' by Collier (2007), using the same list of countries as Buhaug, Falch \& Gleditsch (2010). The logic is that poorer countries are more vulnerable to climate variability and should thus experience a greater risk of conflict due to lower capacity to adapt to negative effects of climatic changes on growth. Although fixed effects may capture the vulnerability of a country to climatic changes, we also address such vulnerability by
Table IV. Predicted economic growth and civil conflict

(1)

World conflict, Africa Conflict,

MA $30 \quad$ MA 30

Predicted growth, lagged $\quad-0.03 \quad-0.16$

Xpolity, lagged

$(0.07)$

$(0.13)$

$0.05 \quad 0.06$

Predicted

$(0.05)$

$(0.05)$

0.01

0.03

lagged

Population growth

$(0.04)$

2.01

15.87

Log population, lagged

$(4.47)$

(11.76)

0.34

$-0.53$

(0.98)

$(0.55)$

Log GDP/capita, lagged

$-1.02$

$-1.78^{*}$

(1.23)

(1.08)

Oil

$1.09^{* * *}$

0.33

$(0.36)$

$(0.56)$

Ethnic fractionalization

$0.97^{*}$

0.18

$(0.57)$

(0.79)

Rough terrain

$-0.01$

0.11

$(0.12)$

$(0.15)$

GDP initial

$-0.00^{* *}$

$-0.00$

$(0.00)$

$(0.00)$

North Africa

$-0.71$

(0.57)

Sub-Saharan Africa

$-1.75^{* * *}$

(0.56)

East Asia

$-1.79^{* * *}$

(0.67)

West Asia

$-1.02^{*}$

(0.56)

$-1.59^{*}$

(0.88)

$-1.26^{*}$

(0.70)

$-0.06$

$-0.01$

Peace years

$(0.07)$

(0.14)

Peace years $^{\wedge} 2$

0.00

0.00

(0.00)

(0.01)

Peace years ${ }^{\wedge} 3$

$-0.00$

$-0.00$

Constant

(0.00)

(0.00)

2.34

(5.90)

13.43

Observations

3,236

(11.90)

Log likelihood

$-293.7$

1,525

$-204.6$

Pseudo R2

0.110

0.0407

Bootstrapped standard errors in parentheses. * significant at $10 \%$; ** significant at $5 \%$; ${ }^{* * *}$ significant at $1 \%$.

running robustness checks with two subsamples: Africa, and all poor countries. Again the results remain the same (See Tables A.V and A.VI in the Web Appendix). 


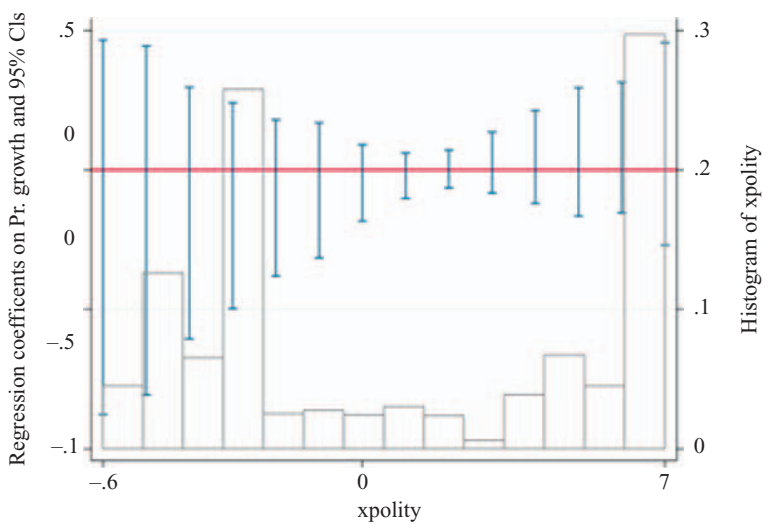

Figure 3. Coefficients of predicted economic growth on civil conflict at different levels of democracy

MA 30 in first stage of model; fixed effects estimator; sample: world.

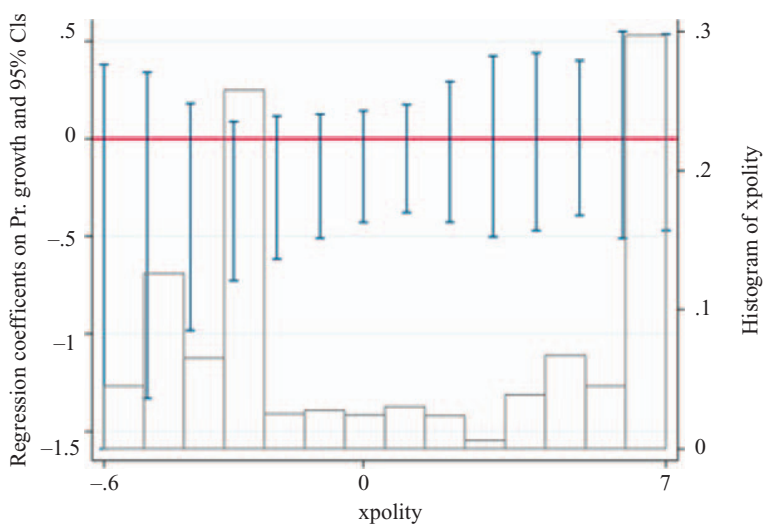

Figure 4. Coefficients of predicted economic growth on civil conflict at different levels of democracy

MA 30 in first stage of model; fixed effects estimator; sample: Africa.

\section{Conclusion}

Whether increasing local or regional climate variability due to large-scale, human-induced changes in the global atmosphere is associated with an increased risk of violent conflict remains contested, both among policymakers and in academic circles. In this article we contribute in two ways to the existing literature on the climate change-conflict nexus. First, we conceptualize this nexus in terms of a two-stage process in which climatic variability affects the probability of violent intrastate conflict via climate effects on economic growth, and where these effects may be contingent on political system characteristics. Second, we employ a measure of climatic variability that has advantages over those used in the existing literature, primarily because it takes into account the adaptation of economic activity to persistent climatic changes.
Our results suggest that climate variability, measured as deviations in temperature and precipitation from their past, long-run levels (a 30-year moving average), does not affect violent intrastate conflict through economic growth. This finding is important because the causal pathway leading from climate variability via (deteriorating) economic growth to conflict is a key part of most theoretical models of the climate-conflict nexus.

While our empirical results provide no support for the climate change-economic growth-conflict pathway, further research is required before we can move towards closure of the debate. In particular, it would be very useful to improve on existing indicators of climatic variability, adaptation to climate variability, and relevant (from the viewpoint of violent conflict) economic performance. For instance, in the absence of appropriate indicators for adaptation it remains difficult to estimate the effect of climatic variability on economic performance and hence on the probability of violent conflict.

Finally, our results offer only very weak support for a mediating effect of political system characteristics. Whereas some of our empirical models suggest that deteriorating economic growth can increase the likelihood of violent conflict in autocratic countries, this finding is fragile with regard to model specification. More research is needed to disentangle the mediating effects of political system characteristics and social institutions more broadly in the growthconflict relationship and explore the channels through which they may be important for adaptation to increased climate variability and for conflict prevention.

\section{Acknowledgements}

We thank Marc Axelrod, Muhammet Bas, Halvard Buhaug, Joshua Busby, Chris Chyba, Andrew Coe, Ariel Dinar, Erik Gartzke, Nils Petter Gleditsch, Cullen Hendrix, Idean Salehyan, Tobias Siegfried, Ole Magnus Theisen, the participants of the 2011 International Relations and Climate Change and 2010 Climate Change and Security Conferences, and four reviewers for comments on previous versions.

\section{Funding}

The research for this article has been carried out with financial support from the Swiss Network for International Studies (SNIS). 


\section{References}

Aldrich, John H (1994) Why Parties? Chicago, IL: University of Chicago Press.

Bächler, Günther; Volker Böge, Stefan Klötzli, Stephan Libiszewski \& Kurt R Spillmann (1996) Environmental Degradation as a Cause of War: Ecological Conflicts in the Third World and Peaceful Ways of Resolving Them. Zürich: Rüegger.

Ban, Ki-moon (2007) A climate culprit in Darfur. Washington Post, 16 June (http://www.washingtonpost.com/wp-dyn/ content/article/2007/06/15/AR2007061501857.html).

Barnett, Jon \& W Neil Adger (2007) Climate change, human security and violent conflict. Political Geography 26(6): 639-655.

Barrios, Salvador; Luisito Bertinelli \& Eric Strobl (2010) Trends in rainfall and economic growth in Africa: A neglected cause of the African growth tragedy. Review of Economics and Statistics 92(2): 350-366.

Beck, Ch; J Grieser \& Bruno Rudolf (2004) A new monthly precipitation climatology for the global land areas for the period 1951 to 2000 (ftp://ftp-anon.dwd.de/pub/data/ gpcc/PDF/pdf_28_precipitation.pdf).

Bergholt, Drago \& Päivi Lujala (2012) Climate-related natural disasters, economic growth, and armed civil conflict. Journal of Peace Research 49(1): 147-162.

Blattman, Christopher \& Edward Miguel (2010) Civil war. Journal of Economic Literature 48(1): 3-57.

Blomberg, Brock \& Gregory D Hess (2002) The temporal links between conflict and economic activity. Journal of Peace Research 46(1): 74-90.

Blomberg, Brock; Gregory D Hess \& Siddharth Thacker (2006) On the conflict-poverty nexus. Economics and Politics 18(3): 237-267.

Brohan, Philip; John J Kennedy, Ian Harris, Simon F B Tett \& Phil D Jones (2006) Uncertainty estimates in regional and global observed temperature changes: A new dataset from 1850. Journal of Geophysical Resources 111, D12106, doi:10.1029/2005JD006548.

Brückner, Markus \& Antonio Ciccone (2010) International commodity prices, growth, and civil war in sub-Saharan Africa. Economic Journal 120(544): 519-534.

Brückner, Markus \& Antonio Ciccone (2007) Growth, democracy, and civil war (http://papers.ssrn.com/sol3/ papers.cfm?abstract_id=1028221).

Bueno de Mesquita, Bruce; Alastair Smith, Randolph M Siverson \& James D Morrow (2003) The Logic of Political Survival. Cambridge, MA: MIT Press.

Buhaug, Halvard (2010) Climate not to blame for African civil wars. PNAS 106(49): 20670-20674.

Buhaug, Halvard; Åshild Falch \& Nils Petter Gleditsch (2010) The bottom billion and climate change. Paper presented to the 51st Annual Convention of the International Studies Association, New Orleans, LA, 17-20 February.

Buhaug, Halvard; Nils Petter Gleditsch \& Ole Magnus Theisen (2010) Implications of climate change for armed conflict. In: Robin Mearns \& Andy Norton (eds) Social
Dimensions of Climate Change: Equity and Vulnerability in a Warming World. New Frontiers of Social Policy. Washington, DC: World Bank, 75-101.

Burke, Marshall B; Edward Miguel, Shanker Satyanath, John A Dykema \& David B Lobell (2009) Warming increases the risk of civil war in Africa. PNAS 106(49): 20670-20674.

Carter, David B \& Curtis S Signorino (2010) Back to the future: Modeling time dependence with binary data. Political Analysis 18(3): 271-292.

Cederman, Lars Erik \& Luc Girardin (2007) Beyond fractionalization: Mapping ethnicity onto nationalist insurgencies. American Political Science Review 101(1): 173-185.

Chassang, Sylvain \& Gerard Padro-i-Miquel (2010) Economic shocks and civil war. Quarterly Journal of Political Science 4(3): 211-228.

Ciccone, Antonio (2011) Economic shocks and civil conflict: A comment. American Economic Review: Applied Economics 3(4): 215-227.

Collier, Paul (2007) The Bottom Billion: Why the Poorest Countries Are Failing and What Can Be Done About It. Oxford: Oxford University Press.

Collier, Paul \& Anke Hoeffler (2004) Greed and grievance in civil war. Oxford Economic Papers 56(4): 563-595.

Dell, Melissa; Benjamin F Jones \& Benjamin A Olken (2008) Climate change and economic growth: Evidence from the last half century. NBER Working Paper 14132 (http:// www.nber.org/papers/w14132).

Deschenes, Oliver \& Michael Greenstone (2007) The economic impacts of climate change: Evidence from agricultural output and random fluctuations in weather. American Economic Review 97(2): 354-385.

Devitt, Conor \& Richard S J Tol (2012) Civil war, climate change, and development: A scenario study for sub-Saharan Africa. Journal of Peace Research 49(1): 129-145.

Dube, Oeindrila \& Juan F Vargas (2008) Commodity price shocks and civil conflict: Evidence from Colombia (http://www.cgdev.org/doc/events/1.28.09/Dube_commo dities_conflict.pdf).

Elbadawi, Ibrahim \& Nicholas Sambanis (2002) How much war will we see? Explaining the prevalence of civil war. Journal of Conflict Resolution 46(3): 307-334.

Fearon, James D \& David D Laitin (2003) Ethnicity, insurgency, and civil war. American Political Science Review 97(1): 75-90.

Garfinkel, Michelle R \& Stergios Skaperdas (2007) Economics of conflict: An overview. In: Todd Sandler \& Keith Hartley (eds) Handbook of Defense Economics. Amsterdam: Elsevier Science, 649-710.

Gizelis, Theodora-Ismene \& Amanda E Wooden (2010) Water resources, institutions, \& intrastate conflict. Political Geography 29(8): 444-453.

Gleditsch, Kristian Skrede (2002) Expanded Trade and GDP Data. Journal of Conflict Resolution 46(5): 712-724. 
Gleditsch, Kristian Skrede \& Andrea Ruggeri (2010) Political opportunity structures, democracy, and civil war. Journal of Peace Research 47(3): 299-310.

Gleditsch, Nils Petter (1998) Armed conflict and the environment: A critique of the literature. Journal of Peace Research 35(3): 363-380.

Gleditsch, Nils Petter; Peter Wallensteen, Mikael Eriksson, Margareta Sollenberg \& Håvard Strand (2002) Armed Conflict 1946-2001: A new dataset. Journal of Peace Research 39(5): 615-637.

Gleditsch, Nils Petter; Håvard Hegre \& Håvard Strand (2009) Democracy and civil war. In: Manus Midlarsky (ed.) Handbook of War Studies III: The Interstate Dimension: Civil Strife, Ethnic Conflict, and Genocide. Ann Arbor, MI: University of Michigan Press, 155-192.

Hegre, Håvard \& Nicholas Sambanis (2006) Sensitivity analysis of the empirical literature on civil war onset. Journal of Conflict Resolution 50(4): 508-535.

Hegre, Håvard; Tanja Ellingsen, Scott Gates \& Nils Petter Gleditsch (2001) Towards a democratic civil peace? Democracy, political change, and civil war, 1816-1992. American Political Science Review 95(1): 33-48.

Hendrix, Cullen S \& Sarah M Glaser (2007) Trends and triggers: Climate, climate change and civil conflict in sub-Saharan Africa. Political Geography 26(6): 695-715.

Hendrix, Cullen \& Idean Salehyan (2012) Climate change, rainfall, and social conflict in Africa. Journal of Peace Research 49(1): 35-50.

Heston, Alan; Robert Summers \& Bettina Aten (2006) Penn World Table Version 6.2. Center for International Comparisons of Production, Income and Prices at the University of Pennsylvania (http://pwt.econ.upenn.edu/php_site/pwt62/ pwt62_form.php).

Hidalgo, Daniel F; Suresh Naidu, Simeon Nichter \& Neal Richardson (2010) Occupational choices: Economic determinants of land invasions. Review of Economics and Statistics 92(3): 505-523.

Homer-Dixon, Thomas F (1999) Environment, Scarcity, Violence. Princeton, NJ: Princeton University Press.

Homer-Dixon, Thomas F \& Jessica Blitt (1998) Ecoviolence: Links among Environment, Population and Security. Lanham, MD: Rowman \& Littlefield.

IPCC (2001) Climate Change 2001: Synthesis Report. Third Assessment Report (AR3) (http://www.grida.no/publications/other/ipcc_tar/).

IPCC (2007) Climate Change 2007: Synthesis Report. Fourth Assessment Report (AR4) (http://www.ipcc.ch/publications_ and_data/publications_ipcc_fourth_assessment_report_ synthesis_report.htm).

IPCC (2010) Statement on the melting of Himalayan glaciers (http:/www.ipcc-wg2.gov/publications/AR4/himalaya-statement-20january2010.pdf).

Jensen, Peter Sandholt \& Kristian Skrede Gleditsch (2009) Rain, growth, and civil war: The importance of location. Defense and Peace Economics 20(5): 359-372.
Keshk, Omar (2003) CDSIMEQ: A program to implement two-stage Probit Least Squares. Stata Journal 3(2): 157-167.

Lomborg, Bjørn (2001) The Skeptical Environmentalist: Measuring the Real State of the World. Cambridge: Cambridge University Press.

Maddala, Gangadharrao S (1983) Limited Dependent and Qualitative Variables in Econometrics. Cambridge: Cambridge University Press.

Marshall, Monty G \& Keith Jaggers (2004) Polity IV Project: Political regime characteristics and transitions, 1800-2009 (http://www.systemicpeace.org/polity/polity 4.htm).

McKee, Thomas B; Nolan J Doesken \& John Kleist (1993) The relationship of drought frequency and duration to time scales. Paper presented to the 8th Convention of Applied Climatology, Anaheim, CA, 17-22 January.

Mendelsohn, Robert; Wendy Morrison, Michael Schlesinger \& Natalia Andronova (1998) Country-specific market impacts of climate change. Climate Change 45(3-4): 553-569.

Mendelsohn, Robert; Ariel Dinar \& Larry Williams (2006) The distributional impact of climate change on rich and poor countries. Environment and Development Economics 11(1): 159-178.

Miguel, Edward \& Shanker Satyanath (2010) Understanding transitory rainfall shocks, economic growth and civil conflict. NBER working paper (16461) (http://www.nber. org/papers/w16461).

Miguel, Edward; Shanker Satyanath \& Ernest Sergenti (2004) Economic shocks and civil conflict: An instrumental variables approach. Journal of Political Economy 112(4): 725-753.

Mitchell, Timothy D \& Philip D Jones (2005) An improved method of constructing a database of monthly climate observations and associated high resolution grids. International Journal of Climate Policy 25(6): 693-712.

Nordås, Ragnhild \& Nils Petter Gleditsch (2007) Climate change and conflict. Political Geography 26(6): 627-638.

Nordhaus, William \& Joseph Boyer (2000) Warming the World: Economic Models of Global Warming. Cambridge, MA: MIT Press.

North, Robert (1984) Integrating the perspectives: From population to conflict and war. In: Nazli Choucri (ed.) Multidisciplinary Perspectives on Population and Conflict. Syracuse, NY: Syracuse University Press, 195-215.

Obama II, Barack Hussein (2009) Climate change speech at the UN General Assembly, 23 September (http://www.nytimes. com/2009/09/23/us/politics/23obama.text.html).

Payne, Roger A (1995) Freedom and the environment. Journal of Democracy 6(3): 41-55.

Plümper, Thomas \& Vera Tröger (2007) Efficient estimation of time-invariant and rarely changing variables in finite sample panel analyses with unit fixed effects. Political Analysis 15(2): 124-139. 
Powell, Robert (2006) War as a commitment problem. International Organization 60(1): 169-203.

Raleigh, Clionadh \& Henrik Urdal (2007) Climate change, environmental degradation and armed conflict. Political Geography 26(6): 674-694.

Reynal-Querol, Marta (2002) Ethnicity, political systems and civil war. Journal of Conflict Resolution 46(1): 29-54.

Salehyan, Idean (2008) From climate change to conflict? No consensus yet. Journal of Peace Research 45(3): 315-326.

Sambanis, Nicholas (2001) Do ethnic and nonethnic civil wars have the same causes? A theoretical and empirical inquiry (Part 1). Journal of Conflict Resolution 45(3): 259-282.

Simon, Julian L (1998) Lebensraum: Paradoxically, population growth may eventually end wars. Journal of Conflict Resolution 33(1): 164-180.

Skaperdas, Stergios (2003) Restraining the genuine homo economicus: Why the economy cannot be divorced from its governance. Economics and Politics 15(2): 135-162.

Snyder, Jack \& Robert Jervis (1999) Civil war and the security dilemma. In: Barbara Walter \& Jack Snyder (eds) Civil War, Insecurity and Intervention. New York: Columbia University, $15-37$.

Stern, Nicholas (2007) The Economics of Climate Change: The Stern Review. Cambridge: Cambridge University Press.

Strand, Håvard (2006) Data on Armed Conflict: Onset and Duration of Interstate Conflict (http://www.prio.no/ CSCW/Datasets/Armed-Conflict/Onset-and-Duration-ofIntrastate-Conflict/).

Theisen, Ole Magnus; Helge Holtermann \& Halvard Buhaug (2011-12) Climate wars? Assessing the claim that drought breeds conflict. International Security 36(3): 79-106.

Tol, Richard (2002) Estimates of the damage costs of climate change. Part II: Dynamic estimates. Environmental and Resource Economics 21(1): 135-160.
Vreeland, James Raymond (2008) The effect of political regime on civil war: Unpacking anocracy. Journal of Conflict Resolution 52(3): 401-425.

WBGU (2008) Climate Change as a Security Risk. London: Earthscan.

Zhang, David D; Peter Brecke, Harry F Lee, Yuan-Qing He \& Jane Zhang (2007) Global climate change, war, and population decline in recent human history. PNAS 104(49): 19214-19219.

VALLY KOUBI, b. 1960, PhD in Political Science (University of Rochester, 1991); Senior Scientist, ETH Zürich (1999- ) and Professor, University of Bern (2005- ); current main interests: international political economy, conflict theory, and environmental politics; recent articles in Journal of Peace Research, Ecological Economics, and British Journal of Political Science.

THOMAS BERNAUER, b. 1963, PhD in Political Science (University of Zürich, 1992); Professor, ETH Zürich (1995- ); current main interests: comparative and international political economy and environmental politics; recent articles in Ecological Economics, British Journal of Political Science, and European Union Politics.

ANNA KALBHENN, b. 1980, Doctor of Sciences (ETH Zürich, 2010); PostDoc, Center for Comparative and International Studies (CIS) and Institute for Environmental Decisions (IED), ETH Zürich (2010); graduate programme participant, European Central Bank (2010- ).

GABRIELE SPILKER, b.1979, PhD in Political Science (ETH Zürich, 2009); Postdoctoral Researcher, ETH Zürich (2009- ); current main interests: international political economy, international cooperation, environmental politics; recent article in British Journal of Political Science. 